\title{
Microsatellite Instability in Ovarian Invasive and Borderline Epithelial Tumors and Comparison with Prognostic Parameters
}

\author{
Overin Invazif ve Borderline Epitelyal Tümörlerinde Mikrosatellit Instabilite ve \\ Prognostik Parametreler ile Karşılaştırılması \\ (D) Filiz Illhan Türkel, (1) Aylin Ege Gül, (1) Sibel Sensu*, (1) Sevinç Hallaç Keser, \\ (1) Nagehan Özdemir Barışık \\ University of Health Sciences Turkey, Kartal Lütfü Kırdar Training and Research Hospital, Clinic of Pathology, İstanbul, Turkey \\ *istinye University Faculty of Medicine, Department of Pathology, Istanbul, Turkey
}

Abstract

\begin{abstract}
Aim: Ovarian cancers, $20 \%$ of which are hereditary, are considered the most lethal gynecological malignancies. Defects on DNA mismatch repair (MMR) genes are responsible for hereditary ovarian tumors related with Lynch syndrome. In this study, we aimed to determine microsatellite instability status in invasive and borderline epithelial ovarian tumors diagnosed via immunohistochemistry in our clinic and compare the results with several prognostic parameters and survival.
\end{abstract}

Methods: In this retrospective study, 159 epithelial ovarian tumors were evaluated for age, tumor type, histological grade and Federation of Gynecology and Obstetrics (FIGO) stage as well as survival. MMR protein expression was immunohistochemically examined and absence of nuclear staining in tumor cells was considered MMR protein expression loss. All prognostic parameters were compared and analysed statistically.

Results: MMR protein expression loss showed no statistically significant relationship with FIGO stage, age, histological grade, and survival. The only correlation was detected between tumor type and MMR protein loss $(p<0.001)$.

Conclusion: Although there are studies comparing microsatellite instability status of the tumors with several prognostic parameters, there is still no consensus on the issue. In this study on ovarian tumors, MMR protein expression loss was related with histological subtypes, but not with other prognostic parameters or survival. We believe that it is worth further investigating in larger studies with higher number of cases.

Keywords: Microsatellite instability, MMR expression, ovarian tumors, immunohistochemisty, prognosis, survival
Amaç: Yüzde 20'si herediter olan over kanseri en ölümcül jinekolojik malignitedir. DNA mismatch onarım (MMR) genlerindeki defektler, Lynch sendromu ile ilişkili herediter over tümörlerinden sorumludur. Bu çalışmada invazif ve borderline epitelyal over tümörlerinde mikrosatellit instabilite araştırılmakta olup sonuçlar çeşitli prognostik parametreler ile karşılaştırılmıştır.

Yöntemler: Bu retrospektif çalışmada 159 epitelyal over tümörü, yaş, tümör tipi, histolojik grade ve Uluslararası Kadın Doğum Dernekleri Federasyonu (FIGO) evreleme yanısıra sağkalım yönünden incelenmiştir. MMR ekspresyonu immünohistokimyasal olarak araştırılmış olup tümör hücrelerinde nükleer boyanma kaybı, MMR ekspresyon kaybı olarak kabul edilmiştir. Tüm prognostik parametreler karşılaştırılmış ve tüm veriler istatistiksel olarak incelenmiştir.

Bulgular: MMR protein ekspresyon kaybı ile FIGO evresi, yaş, histolojik grade ve sağkalım arasında istatistiksel olarak anlamlı ilişki saptanmamıştır. Sadece tümör tipi ile MMR kaybı arasında anlamlı bir korelasyon bulunmuştur $(p<0,001)$.

Sonuç: Tümörün mikrosatellit instabilite durumu ile çeşitli prognostik parametreleri karşılaştıran çalışmalar mevcut olsa da sonuçlar çelişkilidir. Bu çalışmada over tümörlerinde, MMR ekspresyon kaybı histolojik alt tiplerle ilişkili bulunmuş olup diğer prognostik parametreler ve sağkalım ile ilişki saptanmamıştır. Bu konunun daha çok olgu içeren geniş çalışmalar eşliğinde irdelenmesi uygundur.

Anahtar Sözcükler: Mikrosatellit instabilite, MMR ekspresyonu, over tümörü, immünohistokimya, prognoz, sağkalım
Address for Correspondence/Yazışma Adresi: Sibel Sensu, İstinye University Faculty of Medicine, Department of Pathology, İstanbul, Turkey E-mail: sibel.sensu@istinye.edu.tr ORCID: orcid.org/0000-0002-4607-780X Received/Geliş Tarihi: 04 April 2020 Accepted/Kabul Tarihi: 01 November 2020
${ }^{\circ}$ Copyright 2020 by The Medical Bulletin of istanbul Haseki Training and Research Hospital The Medical Bulletin of Haseki published by Galenos Yayınevi. ${ }^{\top}$ Telif Hakkı 2020 istanbul Haseki Eğitim ve Araşıırma Hastanesi Haseki Tıp Bülteni, Galenos Yayınevi tarafından yayınlanmıştır. 


\section{Introduction}

Ovarian cancer is one of the most frequent cancers (age standardized rate $6.4 / 100,000$ person) and has the highest mortality rate among all gynecological malignancies $(1,2)$. Well-accepted prognostic parameters for ovarian cancer are International Federation of Gynecology and Obstetrics (FIGO) stage, age, tumor type and histological grade (2). Approximately one fifth of ovarian tumors are hereditary and Lynch syndrome (LS) is responsible for 10-15\% of these cancers $(2,3)$. In LS, DNA mismatch repair (MMR) genes (mostly MLH1, MSH2, MSH6, and PMS2) have hereditary mutations which lead to the development of microsatellite instability (MSI). In addition, deletions in EPCAM gene responsible for $M S H 2$ gene promoter methylation might be found in LS. Microsatellites are short, repetitive DNA sequences unevenly distributed across the genome (3) on which insertion-deletion type mutations can emerge during DNA synthesis. These mutations, named MSI, are normally repaired by the MMR system. Due to mutations in repair genes, defects might not be repaired and subsequently, mutant copies might accumulate. Mutations developing on microsatellite foci that encode genes might lead to neoplastic alterations $(2,4-7)$. MSI was first discovered in LS-related colon cancer, and subsequently, suggested to have a role in the pathogenesis of various genetic and sporadic cancers. MSI is also reported in approximately $10 \%$ of ovarian cancers $(3,7,8)$.

MSI, which has a well-known prognostic and therapeutical significance in colon and endometrial cancers, might help clarify certain topics related with ovarian tumors, such as growth rate, precursor lesions, prognosis and response to therapy (3). MMR mutation and MSI are detected using methods such as immunohistochemisty (IHC) and polymerase chain reaction (PCR) $(5,7,8)$. Although $P C R$ and gene analysis give some idea on MSI status, these are troublesome, timeconsuming and expensive methods $(5,7,9,10)$. On the other hand, IHC analysis, which is routinely used in many pathology laboratories, is a simple, inexpensive, rapid and convenient method to investigate familial and sporadic MMR defects. In tumors with MMR pathway defects, it is possible to detect loss of one or more protein expressions.

In this study, we aimed to determine MSI status of invasive and borderline epithelial ovarian tumors using the IHC method and evaluate its correlation with several prognostic parameters and survival.

\section{Methods}

One hundred fifty-nine ovarian tumors diagnosed with morphological and immunohistochemical analysis in our pathology clinic between January 2012 and December 2016 were included in the study (ethic committee approval no: 2017/514/104/5, Kartal Dr. Lütfi Kirdar City Hospital). Slides, paraffin blocks and reports belonging to the cases were retrospectively analysed. Sections prepared from the paraffin blocks of selected slides were immunohistochemically stained, as explained below. The cases were reviewed by two pathologists using light microscopy. Demographic data were extracted from patient records. For staging, data from the archives of the medical oncology department were analysed according to the 2014 FIGO staging. For inclusion, the diagnosis of epithelial tumor should be made from surgical specimens, adequate tumor tissue should be present at blocks and slides of the case, positive internal control should be present, and besides, surgical specimen should be included if both biopsy and surgical specimens were available. Consultation cases, cases without paraffin blocks and cases with technically unsatisfactory $\mathrm{IHC}$ results were excluded. According to the Death Registration System, patients alive during the study period were recorded as "survived" cases.

For immunohistochemical examination, $4 \mu \mathrm{m}$ thick sections prepared from formalin fixed-paraffin embedded tissues were used. Tissue sections were taken onto electrostatic loaded slides (isotherm) and placed into $70^{\circ} \mathrm{C}$ incubator for at least 1 hour. All IHC procedures, including deparaffinization and antigen retrieval were performed in a full automated IHC stainer (Ventana BenchMark XT, Ventana Medical Systems, Tucson, AZ).

Instrument-ready, biotinylated, horseradish peroxidase multimer based, ready-to-use kit containing hydrogen peroxide substrate and 3.3'-diaminobenzidine tetrahydrochloride (DAB) chromogen (ultraView ${ }^{\mathrm{TM}}$ Universal DAB Detection Kit, Catalog number 760-500, Ventana Medical Systems, Tuscon, AZ) were used. Staining with MLH1 (Clone: ES05, Dako North America, Ready to use), MSH2 (Clone: FE11, Dako, North America, Ready to use), MSH6 (Clone: EP49, Dako, North America, Ready to use), and PMS2 (Clone: EP51, Dako, North America, Ready to use) antibodies, counterstaining with hematoxylin, dehydration and xylene clearing were performed and the slides were cover-slipped. Inflammatory and stromal cells on slides were considered positive internal control and nuclear staining for each antibody, positive staining. Absence of nuclear staining in tumor cells was interpreted as "loss of MMR proteins".

\section{Statistical Analysis}

Statistical analysis with SPSS version 15.0 software was used to investigate the appropriateness of the variables to normal distribution by using histogram graphs and the Kolmogorov-Smirnov test. Mean, standard deviation and median values were used for descriptive analyses. Two $x$ two grids were compared with Pearson's chi-square and 
Fisher's exact tests. ANOVA was used when variables with normal distribution (parametric) evaluated between more than two groups; the Mann-Whitney $U$ test was used when variables showing non-normal distribution (nonparametric) were evaluated between binary groups; and the Kruskal-Wallis test, for more than two groups. The Spearman correlation coefficient was used to analyze the measurable data with each other. For overall comparison of survival function, log-rank test (Mantel-Cox) was used. A $p$ value of less than 0.05 was considered statistically significant.

\section{Results}

Of the 159 study patients, $68 \%$ was under the age of 60 (18-79 year, mean age: 53.4 ). In $60 \%$ of the cases, tumor type was serous carcinoma and most of the cases $(87 \%)$ were high grade. The most common borderline tumor was borderline mucinous carcinoma. Regarding stage, $43 \%$ of the patients had FIGO1 and $42 \%$ had FIGO3 disease (Table 1).

MMR loss was found in three of 159 cases of ovarian carcinoma ( 1 serious carcinoma, 1 clear cell carcinoma and 1 borderline endometrioid carcinoma). When the relationship between age, tumor type, FIGO stage, histological grade and MMR protein expression loss were analysed, a significant relationship was found only between tumor type and MMR loss $(p<0.001)$. MMR protein expression loss was present in 1 of $2(50 \%)$ borderline endometrioid tumors, one of

\begin{tabular}{|c|c|c|c|}
\hline & & $\mathbf{n}$ & $\%$ \\
\hline \multirow{2}{*}{ Age (year) } & $<60$ & 106 & 66.67 \\
\hline & $\geq 60$ & 53 & 33.33 \\
\hline \multirow{10}{*}{ Tumor type } & Serous carcinoma & 96 & 60.38 \\
\hline & Endometrioid carcinoma & 10 & 6.29 \\
\hline & Mucinous carcinoma & 3 & 1.89 \\
\hline & Clear cell carcinoma & 9 & 5.66 \\
\hline & Transitional cell carcinoma & 1 & 0.63 \\
\hline & Seromucinous carcinoma & 1 & 0.63 \\
\hline & Borderline serous tumor & 18 & 11.32 \\
\hline & Borderline endometrioid tumor & 2 & 1.26 \\
\hline & Borderline mucinous tumor & 16 & 10.06 \\
\hline & Borderline seromucinous tumor & 3 & 1.89 \\
\hline \multirow{2}{*}{$\begin{array}{l}\text { Histological } \\
\text { grade }\end{array}$} & Low grade & 16 & 13.45 \\
\hline & High grade & 103 & 86.55 \\
\hline \multirow{4}{*}{ FIGO stage } & 1 & 69 & 43.40 \\
\hline & 2 & 18 & 11.32 \\
\hline & 3 & 67 & 42.14 \\
\hline & 4 & 5 & 3.14 \\
\hline
\end{tabular}

nine (11\%) clear cell carcinoma and 1 of 96 (1\%) serous carcinoma ( $p<0.001)$ (Table 2$)$. In two patients, only MSH2 protein expression loss and in one patient, both MLH1 and PMS2 protein expression loss were detected (Table 3) (Figure 1 and 2).

Totally, in 159 ovarian cancers, the rate of patients without MMR loss and who were still alive (70.5\%) was below the rate of the all patients who were alive (71.1\%) while the rate of patients who had MMR loss and survived was $67 \%$ (Table 4). The patient who had MMR loss and was paraplegic died in September 2018 due to a nontumoral reason. A statistically significant relationship was not found between MMR protein expression loss and mortality $\left[\chi^{2}(1)=0.044, p>0.005\right]$.

\section{Discussion}

Most frequent hereditary cancer syndromes related with ovaries are hereditary breast and ovarian cancer syndrome (HBOC) and LS. HBOC with BRCA1/2 mutations constitute $90 \%$ of cases and LS, the remaining $10 \%$ (11). LS previously was called hereditary nonpolyposis colorectal cancer, is an autosomal dominant familial syndrome seen at an early age, associated with a genetic predisposition to colorectal, endometrial, gastric or ovarian cancers and rarely found in patients having small intestine, pancreas, and brain tumors. In LS, hereditary mutations are observed in MMR genes. According to the literature, the most frequent histological subtypes in LS-related ovary tumors are clear cell and endometrioid type ovarian cancers $(12,13)$. In a study by Song et al. (14), the mean cumulative risks of ovarian cancers by age 80 years were estimated to be $64 \%, 24 \%$ and $3.7 \%$ in the presence of $B R C A 1, B R C A 2$ and MMR gene mutations.

In the study of Song et al. (14), the median age at diagnosis of hereditary ovarian cancer was 52 for BRCA1 mutation carriers, 57 for BRCA2 mutation carriers and 54 for $M M R$ gene mutation carriers. Vierkoetter et al. (12) reported that patients with MMR protein expression loss were younger than patients without MMR loss (mean age, 47 and 58 years, respectively, $(p=0.014)$ In our study, three patients with MMR protein expression loss were 33, 48 and 60 years old, respectively (mean age: 48.6 year). Although the patients were younger in the group with MMR protein expression loss, we did not find any relationship between age and MMR loss. This may be due to small sample size.

Regarding tumor types, MSI was more frequently reported in several histological subtypes $(10,13,15-17)$. In a study including 42 clear cell ovarian cancers, Cai et al. (18) reported that nine of the cases $(21 \%)$ were related with MSI and high level of MSI was involved in the development of a subset of ovarian clear cell carcinomas. 

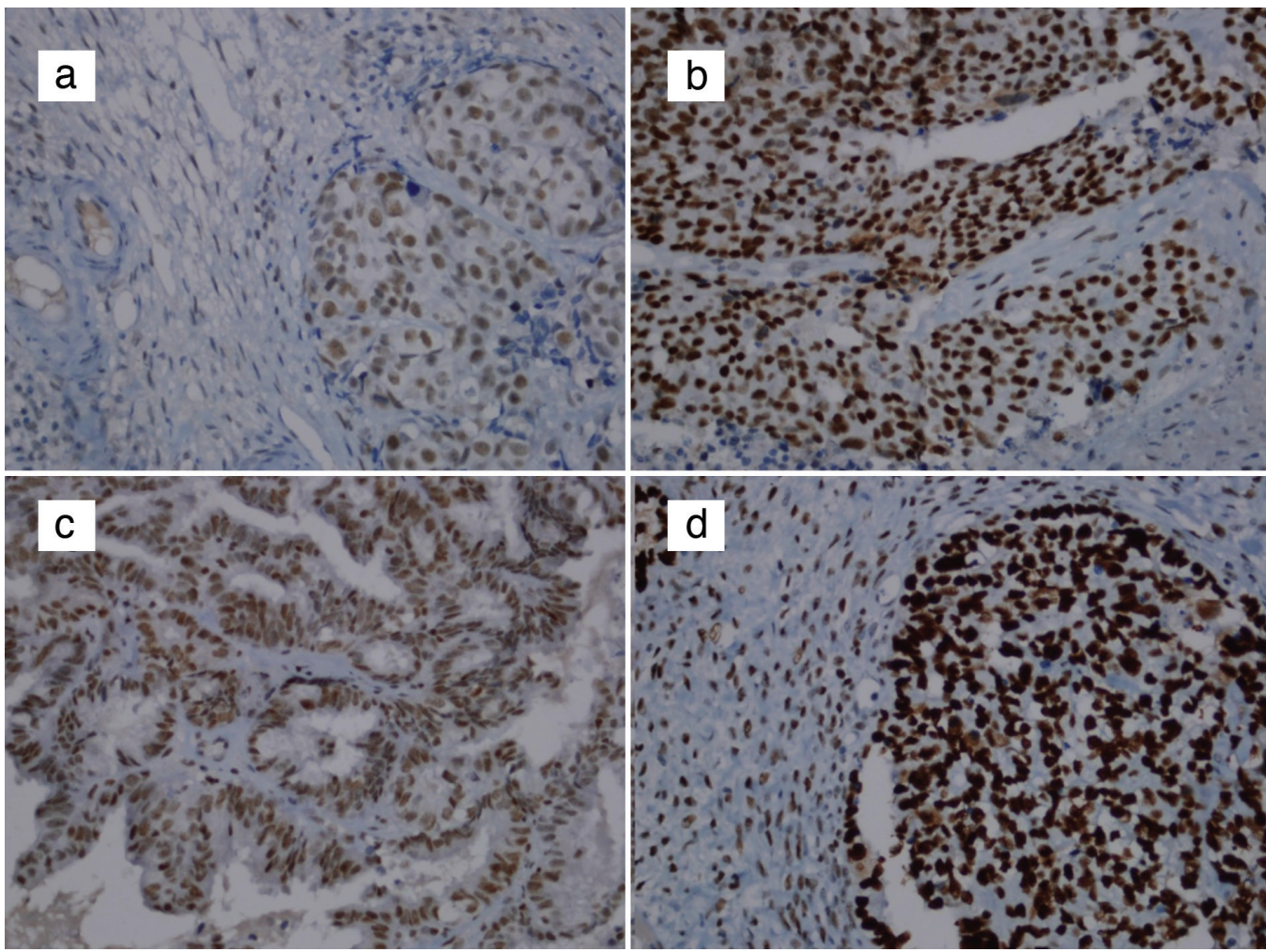

Figure 1. a-d. Immunohistochemical nuclear staining in cases with MMR gene expression (x400). MLH1 (a). MSH2 (b). PMS2 (c). MSH6 (d) MMR: Mismatch repair

\begin{tabular}{|c|c|c|c|c|c|c|}
\hline & & \multicolumn{4}{|c|}{ MMR protein expression } & \multirow{3}{*}{ p } \\
\hline & & \multicolumn{2}{|c|}{ Present } & \multicolumn{2}{|c|}{ Absent } & \\
\hline & & $\mathbf{n}$ & $\%$ & $n$ & $\%$ & \\
\hline \multirow{2}{*}{ Age (year) } & $<60$ & 104 & $(98.11)$ & 2 & $(1.89)$ & \multirow{2}{*}{1.000} \\
\hline & $\geq 60$ & 52 & $(98.11)$ & 1 & $(1.89)$ & \\
\hline \multirow{10}{*}{ Tumor type } & Serous carcinoma & 95 & $(98.96)$ & 1 & $(1.04)$ & \multirow{10}{*}{$<0.001$} \\
\hline & Endometrioid carcinoma & 10 & $(100.00)$ & 0 & $(0.00)$ & \\
\hline & Mucinous carcinoma & 3 & $(100.00)$ & 0 & $(0.00)$ & \\
\hline & Clear cell carcinoma & 8 & $(88.89)$ & 1 & $(11.11)$ & \\
\hline & Transitional cell carcinoma & 1 & $(100.00)$ & 0 & $(0.00)$ & \\
\hline & Seromucinous carcinoma & 1 & $(100.00)$ & 0 & $(0.00)$ & \\
\hline & Borderline mucinous tumor & 16 & $(100.00)$ & 0 & $(0.00)$ & \\
\hline & Borderline seromucinous tumor & 3 & $(100.00)$ & 0 & $(0.00)$ & \\
\hline & Borderline serous tumor & 18 & $(100.00)$ & 0 & $(0.00)$ & \\
\hline & Borderline endometrioid tumor & 1 & $(50.00)$ & 1 & $(50.00)$ & \\
\hline \multirow{4}{*}{ FIGO stage } & 1 & 68 & $(98.55)$ & 1 & $(1.45)$ & \multirow{4}{*}{0.675} \\
\hline & 2 & 17 & $(94.44)$ & 1 & $(5.56)$ & \\
\hline & 3 & 66 & $(98.51)$ & 1 & $(1.49)$ & \\
\hline & 4 & 5 & $(100.00)$ & 0 & $(0.00)$ & \\
\hline \multirow{2}{*}{ Histological grade } & Low grade & 16 & $(100.00)$ & 0 & $(0.00)$ & \multirow{2}{*}{0.574} \\
\hline & High grade & 101 & $(98.06)$ & 2 & $(1.94)$ & \\
\hline
\end{tabular}



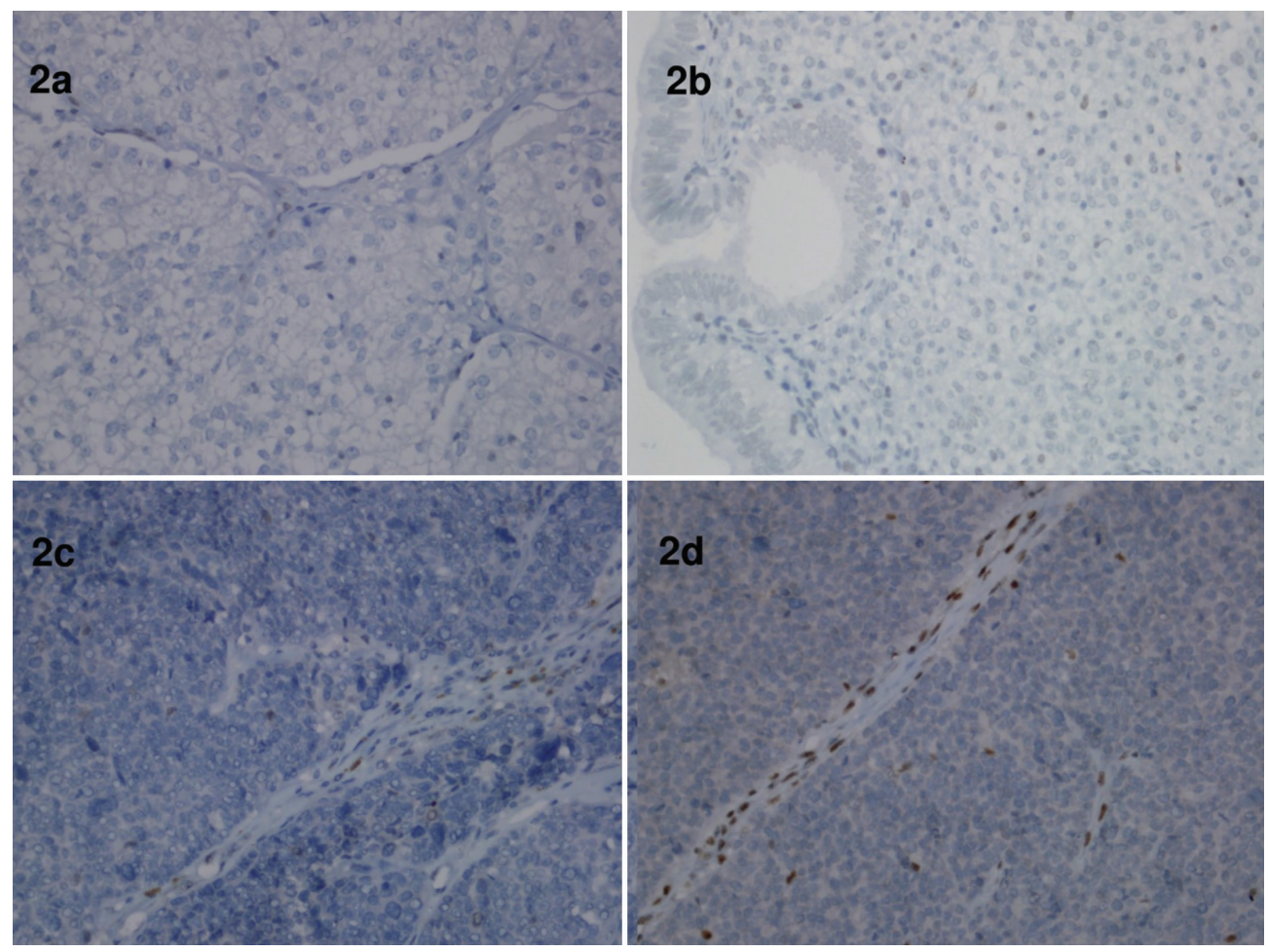

Figure 2. a-d. Absence of immunohistochemical nuclear staining in cases with MMR gene expression loss (x400). MSH2 - clear cell carcinoma (a). MSH2 - borderline endometrioid tumor (b). MLH1 -high grade mixed serous (undifferantiated) carcinoma (c). PMS2 high grade mixed serous (undifferantiated) carcinoma (d)

MMR: Mismatch repair

\begin{tabular}{|l|l|l|l|l|}
\hline \multicolumn{6}{|l|}{ Table 3. MMR subtypes in cases that have MMR loss } \\
\hline & MLH1 loss & MSH2 loss & MSH6 loss & PMS2 loss \\
\hline Case 1 & - & + & - & - \\
\hline Case 2 & - & + & - & - \\
\hline Case 3 & + & - & - & + \\
\hline MMR: Mismatch repair & & \multicolumn{5}{l}{} \\
\hline
\end{tabular}

the correlation between histological subtypes and $M M R$ gene defect, Pal et al. (3) reported that, in ovarian tumors with $M M R$ gene defect, non-serous histological subtypes were dominant and besides, mucinous and endometrioid type ovarian carcinomas were analogous to colon and endometrium cancers of LS (3). Ryan et al. (19), explained that, in LS-related cancers, dominant histological type was endometrioid carcinoma, however, MMR gene defect was also seen in high grade serous carcinomas. In our study, we found a relationship between tumor type and MMR protein expression loss (MMR loss was seen in a borderline endometrioid tumor, clear cell carcinoma and high grade mixed serous carcinoma). Even if we found a statistically significant relationship between MMR protein expression loss and tumor type, our patient group with MMR loss was small and this result should be supported with larger studies.

A retrospective study by the International LS Working

Gras et al. (13) found MSI in only endometrioid and clear cell ovarian cancers and its incidence was $12.5 \%$. Lu et al. (16) found MSI more frequently, in poorly differentiated mucinous and clear cell ovarian cancers, however MSI level was not related with age, tumor differentiation or tumor type, but related with only stage (16). In a metaanalysis of 15 studies $(n=159)$ that investigated Group on correlation between histological grade and MSI protein expression loss reported that LS-related ovarian cancers were mostly in early stage and low grade (20). Colle et al. (7) found that LS-related ovarian cancers were low-grade endometrioid and early stage tumors. Dellas et al. (21) reported that although MSI was more frequent in poorly differentiated cancers ( $p>0.05)$, a statistically 
significant relationship existed only between early stage and MSI ( $p=0.03)$. In our study, one of the patients with MMR loss had borderline endometrioid carcinoma, one, high-grade clear cell carcinoma and the other had highgrade mixed serous carcinoma. Statistical analysis revealed that histological grade was not correlated with MMR loss in our series. Since the stages in our patients with MMR loss were Stage IA, Stage IIB and Stage IIIC, respectively, a statistically significant relationship was not established between MMR loss and FIGO stage. Small sample size might be the reason for not finding any relationship between histological grade, stage and MMR loss; therefore, we think that further analysis might be clarifying.

In a study by Ryan at al. (19) examining 1047 patients with MMR gene mutation, 53 patients had LSrelated ovarian cancer; $85 \%$ of these patients presented at stage $1 / 2$ and 5 years survival was $80 \%$. Mallorca Group prospectively investigated 1942 patients without previous cancer, who were MMR mutation carriers, with colonoscopy and gynecological examination. In this study, 19 of 314 cancers developed during follow-up were ovarian cancers and cumulative ovarian cancer risk at age 70 was $11 \%$ for $M L H 1$ gene defect, $15 \%$ for MSH2 gene defect and $0 \%$ for MSH6 and PMS2 gene defects. Most of the patients with ovarian cancer were younger than 50 and 10 -year survival was $89 \%$ (22). The same study group, in a recent study including LS patients who did not have cancer previously, had early cancers and still alive, found that 5 -year survival was $83 \%$ and 10 -year survival was $74 \%$ in ovarian cancers (23). In our study, one of the three patients with MMR loss was paraplegic and died within 5 years of follow up. Statistical analysis revealed no relationship between patient survival and MMR loss. Nevertheless, we believe that survival should also be further investigated in larger series.

In the study by Mallorca group, MSH6 and PMS2 loss were not found in ovarian cancers. On the contrary, Norquist et al. (24) found MMR gene mutation in eight of 1,915 patients with ovarian cancer and $88 \%$ of these patients had PMS2 or MSH6 gene defect. In 2/3 patients with MSH6 mutation, there were endometrioid and earlystage cancers. The tumor type in four patients with PMS2 mutations was high grade serous carcinoma and was advanced stage. In the study by Song et al. (14), MMR gene mutation was seen in 17 patients and 10 of them had MSH6, four had MSH2, two had MLH1 and one had PMS2 gene mutation. In our study, immunohistochemical analysis with MLH1, MSH2, MSH6, and PMS2 markers revealed that two of three patients with MMR loss had only MSH2 protein expression loss and, one patient had both MLH1 and PMS2 loss. Normally, as a result of MSH2 protein expression loss, due to heterodimeric structure,
MSH6 protein expression loss is also expected. But in two patients with MSH2 loss, no staining loss was seen in MSH6. This might be because of a variable immunohistochemical staining pattern of MSH6 (5). According to Terui et al. (25), $24 \%$ of mutations identified in LS are missense substitutions and this mostly occurs on MSH6 gene. Mutant proteins that develop after missense mutations on genes, might be catalytically inactive but antigenically active (7). In our cases that show only MSH2 loss, MSH6 protein expression loss may not have been found because of missense mutation. In these patients, MSH2 loss might depend on EPCAM gene mutation, thus, we think that MSI status should be clarified with molecular analysis and, EPCAM gene analysis should be added.

Defect on DNA mismatch repair genes occur as a result of two mechanisms, one of which is germline mutations and the other is hypermethylation of $\mathrm{CpG}$ island on MLH1 gene. In normal cells, these islands are not methylated. Since BRAF mutation is seen in $70 \%$ of cancers that occur after MLH1 methylation and is not seen in LS, MMR defect might be sporadic $(26,27)$. When immunohistochemical MLH1 and PMS2 protein expression loss are found in a case, since the tumor may be hereditary as well as sporadic, the patient should be examined for BRAF mutation and MLH1 methylation. Our patient who had both MHL1 and PMS2 loss was old and the tumor type was high-grade serous mixed carcinoma. We assume that in such cases, besides genetic analysis for LS, BRAF mutation should also be analysed for identification of sporadic cases.

In a study by Park and Kim (11) investigating hereditary risk in borderline ovarian tumors immunohistochemically with MLH1, MSH2, BRCA1, and BRCA2 ( $n=32), 3 \%$ of the cases showed $\mathrm{MSH} 2$ protein expression loss. According to this study, although a relationship between borderline tumors and hereditary syndromes was not known, family history should be investigated and necessary tests should be done in suspicious cases (11). In our study, MMR protein expression loss was present in almost 2-3\% of borderline tumors (1/39 borderline tumors). We found MMR protein expression loss in 1 of 2 borderline endometrioid tumors and in which MSH2 protein expression loss was present. In the borderline cases in our study, the incidence of MSH2 protein loss was similar to that in the study by Park and Kim (11) The patient with MMR protein loss had an endometriosis history as well as tumor in family history. Altogether, the results suggest a hereditary tumor in that patient.

In a study evaluating 834 ovarian cancers with IHC and molecular MSI test, Lee et al. (8) reported poor overall concordance (68\%) between the two methods. They suggested that disconcordance might be due to different genetic features of ovarian tumors and also, due 
to benign cases with MSI expression. Dellas et al. (21) found immunohistochemical MMR protein expression loss in 10/41 of patients and IHC could detect only a few (24\%) MSI-positive cases. In our study, IHC detected MMR loss in three of 159 cases (1.8\%). MSI is expected in $10-12 \%$ of ovarian cancers according to literature search, thus, IHC might have detected a small part of actual MSI cases (8).

\section{Study Limitations}

Our study has some limitations. Since some of ovarian cancers diagnosed between 2012 and 2016 were consultation cases, paraffin blocks were not available. Also, in some cases, due to technical problems, IHC did not reveal optimal results. Besides, detailed demographic and clinipathological data were not present in records of patients who received chemotherapy. These, altogether, negatively affected the included number of cases.

\section{Conclusion}

In our study, though MSI status of epithelial ovarian tumors was significantly related with histological subtypes, any relationship with other prognostic parameters and survival was not detected. We suggest that in patients with clear cell and endometrioid ovarian tumors under age 50 years, who have personal and/or family history of malignancy, or have concomitant secondary tumors; immunohistochemical MMR analysis might be helpful for monitoring the patients or patients' relatives. We think that since we had a limited number of cases, further studies with larger series will be clarifying.

\section{Authorship Contributions}

Concept: F.I.T., A.E.G. Design: F.I.T., A.E.G. Data Collection or Processing: F.I.T., A.E.G., S.S., S.H.K., N.Ö.B. Analysis or Interpretation: F.I.T., A.E.G., S.S., S.H.K., N.Ö.B. Literature Search: F.I.T., S.S. Writing: S.S.

Conflict of Interest: The authors declared no conflicts of interest with respect to the authorship and/or publication of this article.

Financial Disclosure: The authors received no financial support for the research and/or authorship of this article.

\section{References}

1. Ministery of Health, General Directorate of Public Health, Turkey Cancer Statistics 2015. Access data: June 2019.

2. Hollis RL, Gourley C. Genetic and molecular changes in ovarian cancer. Cancer Biol Med 2016;13:236-47.

3. Pal T, Permuth-Wey J, Kumar A, Sellers TA. Systematic review and meta-analysis of ovarian cancers: estimation of microsatellite-high frequency and characterization of mismatch repair deficient tumor histology. Clin Cancer Res 2008;14:6847-54.
4. Cai SY, Yang T, Chen Y, Wang JW, Li L, Xu MJ. Gene expression profiling of ovarian carcinomas and prognostic analysis of outcome. J Ovarian Res 2015;8:50.

5. Jung J, Kang Y, Lee YJ, et al. Comparison of the Mismatch Repair System between Primary and Metastatic Colorectal Cancers Using Immunohistochemistry. J Pathol Transl Med 2017;51:129-36.

6. Mukherjee A, McGarrity TJ, Ruggiero F, et al. The revised Bethesda guidelines: extent of utilization in a university hospital medical center with a cancer genetics program. Hered Cancer Clin Pract 2010;8:9.

7. Colle R, Cohen R, Cochereau D, et al. Immunotherapy and patients treated for cancer with microsatellite instability. Bull Cancer 2017; 104:42-51.

8. Lee JH, Cragun D, Thompson Z, et al. Association between IHC and MSI testing to identify mismatch repair-deficient patients with ovarian cancer. Genet Test Mol Biomarkers 2014;18:229-35.

9. Boland CR, Goel A. Microsatellite instability in colorectal cancer. Gastroenterology 2010;138:2073-87.e3.

10. Rosen DG, Cai KQ, Luthra R, Liu J. Immunohistochemical staining of $\mathrm{hMLH} 1$ and $\mathrm{hMSH} 2$ reflects microsatellite instability status in ovarian carcinoma. Modern Pathology 2006;19:1414-20.

11. Park JM, Kim MK. Hereditary risk evaluation for borderline ovarian tumors based on immunohistochemistry. J Menopausal Med 2014;20:14-20.

12. Vierkoetter KR, Ayabe $A R$, VanDrunen $M$, Ahn HJ, Shimizu DM, Terada KY. Lynch Syndrome in patients with clear cell and endometrioid cancers of the ovary. Gynecol Oncol 2014;135:81-4.

13. Gras E, Catasus L, Arguelles R, et al. Microsatellite instability, MLH-1 promoter hypermethylation, and frameshift mutations at coding mononucleotide repeat microsatellites in ovarian tumors. Cancer 2001;92:2829-36.

14. Song $H$, Cicek MS, Dicks $E$, et al. The contribution of deleterious germline mutations in BRCA1, BRCA2 and the mismatch repair genes to ovarian cancer in the population. Hum Mol Genet 2014;23:4703-9.

15. Jensen KC, Rajan M, Putcha GV, et al. Microsatellite instability and mismatch repair protein defects in ovarian epithelial neoplasms in patients 50 years of age and younger. Am J Surg Pathol 2008;32:1029-37.

16. Lu Y, Liu XS, Wang YX, Song HY, Zhong N. Study of microsatellite instability in epithelial ovarian tumors. Beijing Da Xue Xue Bao Yi Xue Ban 2006;38:62-5.

17. Stasikowska-Kanicka O, Stawerski P, Wagrowska-Danilewicz M, Danilewicz M. Immunohistochemical analysis of hMLH1 and hMSH2 proteins in serous ovarian tumours. Pol J Pathol 2009;60:174-8.

18. Cai KQ, Albarracin C, Rosen D, et al. Microsatellite instability and alteration of the expression of hMLH1 and hMSH2 in ovarian clear cell carcinoma. Hum Pathol 2004;35:552-9. 
19. Ryan NA, Evans DG, Green K, Crosbie EJ. Pathological features and clinical behavior of Lynch syndrome-associated ovarian cancer. Gynecol Oncol 2017;144:491-5.

20. Watson P, Butzow R, Lynch HT, et al. The clinical features of ovarian cancer in hereditary nonpolyposis colorectal cancer. Gynecol Oncol 2001;82:223-8.

21. Dellas A, Puhl A, Schraml P, et al. Molecular and clinicopathological analysis of ovarian carcinomas with and without microsatellite instability. Anticancer Res 2004;24:3619.

22. Møller P, Seppala T, Bernstein I, et al. Cancer incidence and survival in Lynch syndrome patients receiving colonoscopic and gynaecological surveillance: first report from the prospective Lynch syndrome database. Gut 2017;66:464-72.

23. Møller P, Seppala TT, Bernstein I, et al. Cancer risk and survival in path_MMR carriers by gene and gender up to 75 years of age: a report from the Prospective Lynch Syndrome Database. Gut 2018;67:1306-16.

24. Norquist BM, Harrell MI, Brady MF, et al. Inherited Mutations in Women With Ovarian Carcinoma. JAMA Oncology 2016;2:482-90

25. Terui $H$, Akagi K, Kawame H, Yura K. CoDP: predicting the impact of unclassified genetic variants in MSH6 by the combination of different properties of the protein. J Biomed Sci 2013;20:25.

26. Richman S. Deficient mismatch repair: Read all about it (Review). Int J Oncol 2015;47:1189-202.

27. Capper D, Voigt A, Bozukova G, et al. BRAF V600E-specific immunohistochemistry for the exclusion of Lynch syndrome in MSI-H colorectal cancer. Int J Cancer 2013;133:1624-30. 